\title{
Effect of operating conditions in soil aquifer treatment on the removals of pharmaceuticals and personal care products
}

\author{
Kai $\mathrm{He}^{1}{ }^{*}$,Shinya Echigo ${ }^{1}$ and Sadahiko Itoh $^{1}$ \\ ${ }^{1}$ Department of Environmental Engineering, Graduate School of Engineering, Kyoto \\ University, Nishikyo, Kyoto 615-8540, Japan \\ *Corresponding author's e-mail: hekai@urban.env.kyoto-u.ac.jp
}

\begin{abstract}
Soil aquifer treatment (SAT) is an alternative advanced treatment for wastewater reclamation, and it has the potential to control micropollutants including pharmaceuticals and personal care products (PPCPs). However, the relationship of operating conditions in SAT and removals of micropollutants was not clear. In this study, the effects of operating conditions on the removals of PPCPs were evaluated by using lab-scale columns and plant pilot-scale reactors under different operating conditions. Firstly, weathered granite soil (WGS), standard sand (SAND) and Toyoura standard sand (TS) have different soil characteristics such as total organic carbon (TOC) and cation exchange capacity (CEC). In the columns with these packing materials, the removals of carboxylic analgesics and antilipdemics were effective regardless packing materials. The removals of antibiotics were more effective in WGS than in TS and SAND, indicating high TOC and CEC enhance the sorption in SAT. Secondly, with the extention of hydraulic retention time (HRT), the removals of sulfamethoxazole, acetaminophen, crotamiton, and antipyrine were improved in WGS columns, and adaptable biodegradation for moderately removable PPCPs was formed. Thirdly, the removal efficiencies of sulfamethoxazole and crotamiton were higher in the WGS column under vadose condition than in the WGS column under saturated condition, because of aerobic condition in WGS column under vadose condition. Though long HRT and vadose condition had positive influence on the removals of several PPCPs such as sulfamethoxazole, WGS column with an HRT of 7 days under saturated condition removed most PPCPs.
\end{abstract}

\section{KEYWORDS}

PPCPs; SAT; Packing materials; Hydraulic retention time; Saturated condition

\section{1.\# INTRODUCTION}

Micropollutants including pharmaceuticals and personal care products (PPCPs) are ubiquitous (from $\mathrm{ng} / \mathrm{L}$ to low $\mu \mathrm{g} / \mathrm{L}$ ) in the effluents from wastewater treatment plants (WWTPs) (Boyd et al., 2003; Ellis, 2006; Focazio et al., 2008; Kim et al., 2009; Lin et al., 2009; Okuda et al., 2009; Ort et al., 2010; Stuer-Lauridsen et al., 2000; Yonetani et al., 2012), and they may pose risks to both human and ecosystems (Nakada et al., 2010). Thus, an additional process after the treatments in WWTPs is required on the improvement of water quality(Suárez et al., 2008), and soil aquifer treatment (SAT) is an option for this purpose. Though SAT has benefits such as low operating cost and stable performance (Gerba et al., 1991; Idelovitch and Michail, 1984), not all micropollutants are degraded completely in SAT(Hernández et al., 2012). Degradation of micropollutants including EDCs and PPCPs in soil were affected by environmental conditions such as temperature, $\mathrm{pH}$, moisture content, organic carbon, the presence of specific microorganisms, and DO conditions (Aga, 2007; Colucci et al., 2001; Monteiro and Boxall, 2009). Schaffer et al. (2015) demonstrated that the 
hydrophobicity of compounds and the solid organic matter in SAT column enhanced the sorption of neutral and anionic compounds. However, our understanding on the relationship between these operating conditions and the properties of micropollutants is still poor, and the roles of SAT as an additional process to wastewater treatment remain unclear.

This study addresses these unanswered questions by monitoring the removals of various PPCPs in SAT. PPCPs are an ideal group of compounds for this purpose because of their variety of chemical properties (Suárez et al., 2008), giving insight into the removal mechanism in SAT. The removals of PPCPs in SAT were assessed in both field- and laboratory-scale studies: Drewes et al. (2001) mentioned that six to ten years of saturated anoxic flow led to $60 \%$ removal of X-ray contrast media in a field-scale groundwater recharge. In another experiment, the removal efficiency of sulfamethoxazole in a bank filtration system was $95 \%$, but only $53 \%$ in an artificial recharge system(Grünheid et al., 2005). Xu et al. (2009) observed that the removal of six PPCPs varied in four agricultural soils. These studies indicated that the operating conditions influenced the removals of PPCPs in SAT, but the number of target compounds is limited.

Though previous studies revealed the removal characters of several PPCPs in SAT, no study systematically evaluated the relationship between the removals of PPCPs and operating conditions with respected to the properties of PPCPs. In this study, the effects of operating conditions (packing materials, hydraulic retention time (HRT), and saturated conditions) on the removals of PPCPs were evaluated in the SAT columns under setting operating conditions. Furthermore, the cooperation between SAT and conventional activated sludge (CAS) treatment was discussed with respected to the removals of micropollutants.

\section{2.\# MATERIALS AND METHODS}

In this study, the experiments were divided into three parts: the effects of 1) packing materials, 2) HRT and 3) vadose condition on the removals of PPCPs in SAT. Firstly, columns packed with weathered granite soil (WGS), standard sand (SAND) and Toyoura standard sand (TS) were operated to evaluate the effects of packing materials on the removals of PPCPs. Secondly, two series of experiments were conducted to evaluate the effect of HRT. In the first set, WGS with HRTs of typical SAT operation (i.e., 7, 30 and 180 days); in the second set, shorter HRTs (i.e, 4 hours, 8 hours, 1 day and 7 days) were used to understand the removals of PPCPs in SAT with short-term HRT. the experiments were divided into two parts of time-scales: WGS columns with HRTs of 7, 30, and 180 days were evaluated to understand the influences of the long-term HRTs (day-scale) in SAT as well as WGS columns with HRTs of 7 days, 1 day, 8 hours and 4 hours for the short-term HRTs (hourscale). Thirdly, WGS columns under vadose and saturated conditions were operated to evaluate the effect of vadose condition on the removals of PPCPs in SAT.

\section{1.\# Reagents}

In this study, 42 PPCPs were selected according to the frequency of their detection in the effluents of WWTPs (Okuda et al., 2009; Yonetani et al., 2012) (Table 1). DEET was the abbreviation of $N, N$-Diethyl-meta-toluamide. CAM and SDIME were dissolved into acetone (Okuda et al., 2009). CPFX, LVFX, NRFX, and ERFX were dissolved into a water/acetonitrile solution, and all the other PPCPs were dissolved into acetonitrile to prepare the stock solutions. For the analysis of PPCPs with a LC-MS/MS system, formic acid, methanol, and acetonitrile (LC-MS grade) were used for the preparation of mobile phase. 
100 CAF and CTC were purchased from Cosmo Bio Co., Ltd; IPP and LVFX were purchased 101 from Tokyo Chemical Industry Co., Ltd; ATP, LCM, ATL, AZM, CPFX, DTZ, ERFX, FNP, 102 FSM, GFB, MFA, OTC, SMT, TC, IBP, SMETH, and TRM were purchased from Funakoshi 103 Co., Ltd, and all other compounds were purchased from Wako Pure Chemical Co., Ltd. All 104 the aqueous solutions were prepared with ultra-pure water produced with Millipore 105 Academic-A10 system (hereinafter call MQW).

\section{2.\# Feed water}

An effluent from an actual WWTP using anaerobic-anoxic/oxic $\left(\mathrm{A}_{2} \mathrm{O}\right)$ process (hereinafter called $\mathrm{A}_{2} \mathrm{O}$ water) in Kyoto City (Japan) was used as the feed water for the experiments. Water quality of feed water was shown in Table 3.

\section{3.\# SAT columns setting}

In this study, WGS, SAND and TS were used as the packing materials for SAT columns. WGS is a typical soil in the west of Japan, and TS is a typical sand in Japan (van Wijhe, 2002). The characteristics of these packing materials (WGS, SAND and TS) were shown in Table 2. WGS has higher cation exchange capacity (CEC) and total organic carbon (TOC) than SAND and TS.

In order to evaluate the influence of operating conditions of SAT on the removals of PPCPs, SAT columns under different conditions were operated. Two large lab-scale acrylic columns (TS-7 and Sand-7; i.d., $15 \mathrm{~cm}$; H, $150 \mathrm{~cm}$ ), two medium lab-scale acrylic column (WGS-7 and WGS-1; i.d., $8 \mathrm{~cm}$; H, $100 \mathrm{~cm}$ ), two small lab-scale acrylic columns (WGS-4H and WGS-8H; i.d.,5 cm; H, $40 \mathrm{~cm}$ ), and three pilot plant-scale stainless steel reactors (WGS-30, WGS-180, and WGS-Sat; L, $1.5 \mathrm{~m} ; \mathrm{W}, 1.5 \mathrm{~m} ; \mathrm{H}, 3.0 \mathrm{~m}$ ) were used. The operating conditions of columns are summarized in Table 4. The concentration of dissolved organic carbon (DOC) ranged from 0.806 (WGS-180) to $2.551 \mathrm{ng} / \mathrm{L}$ (WGS-4H), and $\mathrm{pH}$ of SAT effluents was at a steady range from 6.26 to 7.11 . These values did not show clear difference between samples, and these indicated that the performances of SAT columns were stable in long-term operation. Feed water for large lab-scale acrylic columns was fed by peristaltic pumps (755480, Thermo Fisher Scientific), and feed water for medium and small lab-scale acrylic column was fed by peristaltic pumps (SJ1220, ATTA). The operation of the large lab-scale acrylic columns, medium lab-scale acrylic columns, and small lab-scale acrylic columns started in January 2012, April 2013, and July 2014, respectively.

Feed water for pilot plant-scale stainless steel reactors was pumped into reactors by centrifugal pumps. The soil pilot-plant scale reactors consisted of the bottom layer (gravel level) and the soil layer. For the vadose condition, the water head was maintained at $20 \mathrm{~cm}$ below the top of the WGS/SAND layer. For the saturated condition, the water head was maintained at $20 \mathrm{~cm}$ above the top of the WGS layer. Sand pilot plant-scale reactor started in October 2011; and WGS pilot plant-scale reactors started in April 2012. The schematic of pilot plant-scale reactors is shown in Figure 1.

\section{4.\# Analytical methods}

$200 \mathrm{~mL}$ of water samples for LC-MS/MS measurement was filtered by glass fiber membrane filters (ADVANTEC GF-75, $90 \mathrm{~mm}$ ). All filtrates were concentrated with solid-phase extraction (SPE). The SPE cartridge (Oasis HLB cartridges (Waters), $250 \mathrm{mg}$ bed) was conditioned with $5 \mathrm{~mL}$ of methanol and $5 \mathrm{~mL}$ of MQW at $\mathrm{pH} 3$ (adjusted with hydrochloric acid). Samples were pumped through the cartridge at a flow rate of $10 \mathrm{~mL} / \mathrm{min}$ for 20 minutes. After drying the SPE cartridges with nitrogen gas, the retained compounds were eluted with 5 
$150 \mathrm{~mL}$ of methanol. The eluted solution was evaporated to dryness under a gentle stream of 151 nitrogen gas (Okuda et al., 2009; Yonetani et al., 2012). The residues of the $\mathrm{A}_{2} \mathrm{O}$ water and

152 SAT effluent samples were re-dissolved in $2 \mathrm{~mL}$ and $1 \mathrm{~mL}$ of $0.1 \%$ formic acid-acetonitrile $153(90 / 10, \mathrm{v} / \mathrm{v})$, respectively. The solution was analyzed by LC-MS/MS. In this study, 154 prominence 20A (Shimadzu system) interfaced to 4000 QTRAP (AB SCIEX) with a C-18 column (Kinetex, $2.1 \mathrm{~mm}, 2.6 \mu \mathrm{m}$ ) and a VP-ODS column (Shimadzu, $4.6 \mathrm{~mm}, 4.6 \mu \mathrm{m}$ ) was used for negative mode analysis and positive mode analysis, respectively. In the LC-MS/MS measurement, multiple-reaction monitoring (MRM) mode was chosen for the quantification of target compounds. Operating conditions of LC-MS/MS were optimized by using MQW with the addition of standard compounds. LC-MS/MS conditions, MRM parameters, and LC gradient for the separation of target compounds were shown in Tables S1-S7 (supplement information).

The recoveries of the target compounds were determined by fortifying standard compounds into $\mathrm{A}_{2} \mathrm{O}$ water or SAT effluent. The fortified sample and the blank (i.e. $\mathrm{A}_{2} \mathrm{O}$ water without fortification) were concentrated as described above. These samples were prepared in duplicate, and the average recovery rate of each target compound in $\mathrm{A}_{2} \mathrm{O}$ water and SAT effluent was shown in Figure S1 (Supplementary information). The standard curve was checked before each measurement of PPCPs, and the recovery experiment was checked about every two months. The method of standard addition was used for calculating the recoveries of PPCPs referring to the works of Okuda et al. (2009).

\section{3.\# RESULTS AND DISCUSSION \\ 3.1.\# Occurrence of PPCPs in the $\mathrm{A}_{2} \mathrm{O}$ water}

The concentrations of PPCPs in $\mathrm{A}_{2} \mathrm{O}$ water were summarized in Figure 3. The total concentration of target PPCPs in $\mathrm{A}_{2} \mathrm{O}$ water was more than $5000 \mathrm{ng} / \mathrm{L}$. Okuda et al. (2008) reported that total concentration of 66 PPCPs in the WWTPs effluents was up to approximately $10000 \mathrm{ng} / \mathrm{L}$. Yang et al. (2011) reported that total concentration of 19 PPCPs in the effluent after membrane treatment was up to approximately $2000 \mathrm{ng} / \mathrm{L}$. Referring to the works of Tootchi (2010), the concentration of PPCP above $20 \mathrm{ng} / \mathrm{L}$ was considered as a high concentration in the water treatment. Antibiotics and analgesics were the major PPCPs in $\mathrm{A}_{2} \mathrm{O}$ water (Figure 3). This result confirmed that CAS treatment cannot remove PPCPs completely.

For antibiotics, CAM, AZM, LVFX, and CPFX were observed at relatively high concentrations (769, 175, 28, and $23 \mathrm{ng} / \mathrm{L}$, respectively), while ERFX was not detected in the $\mathrm{A}_{2} \mathrm{O}$ water. These were in agreement with other studies on the occurrences of antibiotics in wastewater effluents (Narumiya et al., 2009; Yasojima et al., 2006). For analgesics, CRT was the most abundant in $\mathrm{A}_{2} \mathrm{O}$ water ( $806 \mathrm{ng} / \mathrm{L}$ on average). In previous studies, CRT was also detected at relatively high concentration $(1240 \mathrm{ng} / \mathrm{L}$ and $921 \mathrm{ng} / \mathrm{L}$, respectively) in the effluents of several WWTPs (Nakada et al., 2006; Narumiya et al., 2009). In addition, KTP, DCF, MFA, ACEAM and NPX were also dominant in $\mathrm{A}_{2} \mathrm{O}$ water $(639,80,75,17$, and 34 $\mathrm{ng} / \mathrm{L}$ respectively), which were in agreement with the works of Tixier et al. (2003. In this study, IBP was not detected in the $\mathrm{A}_{2} \mathrm{O}$ water. Kobayashi et al. (2006) and Narumiya et al. (2009) mentioned that IBP was detected at a relatively high concentration in wastewater influents, but not detected in wastewater effluents. This could be attributed to biodegradation in treatment (Kraigher et al., 2008; Nakada et al., 2006; Radjenović et al., 2009). 
199 For other groups of selected PPCPs, BZF, SLP, TEP, DEET, CAF, DSP and FSM were 200 observed at high concentrations (193, 397, 108, 455, 94, 237, and $203 \mathrm{ng} / \mathrm{L}$, respectively). 201 These PPCPs were also detected at relatively high concentration in the effluents of other

The selected PPCPs have a wide range of physical-chemical properties and complex chemical structures (In Table 1, their $K_{\mathrm{oc}}$ values (i.e., soil organic carbon-water partition coefficient) range from 0.69 to 61000 , and their $\mathrm{p} K_{\mathrm{a}}$ values range from 1.4 to 9.5 .), and were widely detected in $\mathrm{A}_{2} \mathrm{O}$ water. Thus, PPCPs were appropriate as the indicators of micropollutants in SAT. In addition, because the concentrations of PPCPs fluctuated in $\mathrm{A}_{2} \mathrm{O}$ water and SAT effluents during the monitoring period, the monthly average values $(n=11)$ were used to calculate the removal efficiencies of SAT in the following parts (Karnjanapiboonwong et al., 2011). Considering the concentration of PPCPs in $\mathrm{A}_{2} \mathrm{O}$ water in Figure 3 (>10 ng/L) and the frequencies of detection (GFB, ATP, LCM, and IPP), 29 PPCPs were chosen as target compounds to evaluate the removal characters of PPCPs in SAT under different operating conditions.

\section{2.\# Effects of packing materials on the removals of PPCPs}

Their removal efficiencies in SAT were divided into four levels: 1) highly efficient ( $>90 \%)$, 2 ) efficient $(80-90 \%), 3)$ moderate $(50-80 \%)$ and 4$)$ poor $(<50 \%)$ (Matamoros et al., 2008b; Reif et al., 2011; Reungoat et al., 2011). The removals of PPCPs in SAT were mainly attributed to the sorption and biodegradation (Hoppe-Jones et al., 2012). Removal efficiencies of selected PPCPs (max, average, and min values) in SAT columns of 7 days packed with weathered granite soil (WGS-7), SAND (Sand-7) and Toyoura sand (TS-7) were shown in Figure 4.

Among antibiotics, effective removals (above 90\%) were observed for CAM, LCM, and AZM in WGS-7 and Sand-7. In TS-7, the removal efficiencies of CAM, LCM and AZM were $71.1 \%, 52.5 \%$ and $92.7 \%$, respectively, which were less efficient than those in WGS-7 and Sand-7. Polar (2007) mentioned that macrolides (i.e., CAM, LCM and AZM) were readily adsorbed in bank filtration. In addition, Schlüsener and Bester (2006) studied the persistence of macrolides, and the half lives of macrolides were longer than 20 days. Thus, abiotic process mainly contributed to their effective removals in SAT columns with HRT of 7 days. The $\mathrm{p} K_{\mathrm{a}}$ values of CAM, LCM, and AZM ranged from 7.60 to 8.99 (above the $\mathrm{pH}$ in SAT columns (i.e., approximately 6.0)), and significant ionic interaction was expected to be significant for their removals in SAT (Göbel et al., 2005; Sibley and Pedersen, 2007). Cation exchange is an important ionic interaction, and contributed to the sorption of antibiotics in soil (Figueroa et al., 2004; Sassman and Lee, 2005). WGS and SAND have higher CEC values (15.6 and $2.39 \mathrm{meq} / 100 \mathrm{mg}$, respectively) than TS $(0.192 \mathrm{meq} / 100 \mathrm{mg})$. Gao and Pedersen (2005) mentioned that CEC had positive influence on the sorption of sulfonamide antimicrobial agent to clay minerals. Thus, the effective removals of CAM, LCM, and AZM were attributed to the CEC of WGS and SAND.

LVFX, one of fluoroquinolones, was removed by $97.7 \%, 85.3 \%$, and $61.7 \%$ in WGS-7, Sand-7, and TS-7, respectively, and their high removals in soil were also reported in other works (Drillia et al., 2005; Picó and Andreu, 2007; Tolls, 2001). Their effective removals were attributed to abiotic degradation in SAT because their resistance on biodegradation was expected in solid matrices such as soil and sand (Golet et al., 2003; Picó and Andreu, 2007; Uslu et al., 2008). The $K_{\text {oc }}$ value of LVFX (44143 mL/g) is high as well as other fluoroquinolones (CPFX, ERFX and NRFX, their $K_{\mathrm{oc}}$ values range from $15800-61000 \mathrm{~mL} / \mathrm{g}$ ), 
and $K_{\mathrm{oc}}$ can enhance the immobility of compounds in soil, and compounds with $K_{\mathrm{oc}}$ values of more than $5000 \mathrm{~mL} / \mathrm{g}$ were expected to be immobile in soil (Khan and Anjaneyulu, 2005). Thus, the effective removals of LVFX in columns were attributed to the sorption because of LVFX more effectively than TS-7. The TOC values of WGS, TS and SAND were $0.0159 \%$, $0.0144 \%$ and $0.0094 \%$, respectively. Soil organic matter (SOM) enhanced the sorption of micropollutants in soil (Bot and Benites, 2005), and this explained the improvement of removals of LVFX in WGS-7 column compared with TS-7. Furthermore, for the characteristics related to sorption, not only organic content of soil influenced the sorption of micropollutants in soil (Yu et al., 2009), but also surface characters of soil such as specific surface area strongly enhanced the sorption (Bailey and White, 1970; Tolls, 2001). In this study, WGS and SAND have much higher values of specific area $\left(5.95\right.$ and $\left.2.40 \mathrm{~m}^{2} / \mathrm{g}\right)$ than TS $\left(0.812 \mathrm{~m}^{2} / \mathrm{g}\right)$. This can explain the difference of removal efficiencies of LVFX between Sand-7 and TS-7. Furthermore, TOC and specific area of soil enhanced the sorption of antibiotics having high $K_{\mathrm{oc}}$. Overall, WGS showed better performance on the sorption of antibiotics, and this is attributed to high TOC, CEC, and specific area of WGS. From the perspective of practical use, WGS was suitable for SAT packing materials to remove antibiotics in wastewater effluents.

Among the analgesics and antilipidemics PPCPs, the removal efficiencies of DCF, KTP, NPX, MFA, BZF, CFB, and GFB (carboxylic PPCPs) were in the range of $81.8 \%$ and $99.6 \%$ (in WGS-7); $80.6 \%$ and $99.0 \%$ (in Sand-7); 84.9\% and 98.7\% (in TS-7). Their removals in SAT are all high regardless packing materials. In addition, the removal efficiencies of FSM, another carboxylic PPCP, were 94.4\%, 98.8\%, and 99.6\% in WGS-7, Sand-7, and TS-7, respectively. The removal efficiencies of DEET were $70.3 \%, 55.3 \%$, and $54.2 \%$ in WGS-7, Sand-7, and TS-7, respectively. In previous studies, these compounds were biodegradable in treatments including soil and activated sludge treatments (Drewes et al., 2006; Fang et al., 2012; Onesios et al., 2009; Tiehm et al., 2011). Thus, biodegradable PPCPs were similarly removed efficiently regardless packing materials (WGS, SAND and TS). For amide PPCPs (Nakada et al., 2007) (ATP, IPP, CRT, PRM, and CBM), their removals were poor regardless packing materials (less than 50\%) except the removal of ATP in Sand-7 (57.2\%). Furthermore, the concentration of CBM increased in SAT columns with different packing materials $(78.8 \%, 114.0 \%$ and $52.5 \%$ in WGS-7, Sand-7 and TS-7, respectively). For persistent PPCPs, their removals were still poor in SAT columns with different packing materials. Kasprzyk-Hordern et al. (2009) also reported that CRT and CBM were removed only slightly in soil infiltration. For persistent PPCPs, their poor removals, more specifically, negative removals would be discussed in the following part. Similar biodegradation among columns with different packing materials could be attributed to the similar microbial metabolic patterns among the top layers of SAT because of the continuous usage of wastewater effluent (Takabe et al., 2014). In order to evaluate the removal mechanism of SAT, control experiment by using sterilization will be required in our future study. Packing materials had little influence on the biodegradation in SAT, and the effect of HRT on biodegradation would be discussed in the following part.

In summary, WGS possessing high TOC, CEC and specific surface showed strong sorption for the removals of antibiotics, but packing materials had little influence on the biodegradation of SAT. 


\section{3.\# The effect of HRT on PPCP removals in SAT}

298 In this section, the removal efficiencies of target PPCPs in SAT columns of 7, 30 and 180 299 days packed with weathered granite soil (WGS-7, WGS-30 and WGS-180) were shown in 300 Figure 5. The removals of LVFX were efficient in WGS columns regardless HRT (above efficient (above 90\%). Rapid sorption of compounds was also observed in other works (Allaire et al., 2006; Song and Guo, 2014). Thus, HRT had little influence on the sorption process in SAT. For SMETH, another antibiotic agent, its removal efficiencies were low in WGS columns with an HRT of 7 days. SMETH possesses sulfonamide group, and the persistence of sulfonamide compounds was observed in soil (Accinelli et al., 2007; Boxall et al., 2002; Yang et al., 2009). However, the removal of SMETH was enhanced by extending HRT (81.5\% in WGS-180). Gimbel et al. (2006) demonstrated that long HRT enhanced the removal of SMETH in slow sand filters. Furthermore, Stoob et al. (2006) reported that the concentration of spiked SMETH decreased with extending contact time in soil. These indicated that the effective removals of SMETH in WGS columns were attributed to the sufficient HRT.

For carboxylic PPCPs (DCF, KTP, NPX, MFA, BZF, CFB, GFB, and FSM), their removals in WGS columns were efficient with HRTs of 7, 30, and 180 days, respectively (above 80\%). The removals of NPX were more efficient in SAT with an HRT of 7 days or longer $(81.8 \%$, $83.8 \%$ and $87.5 \%$ in WGS-7, WGS-30, and WGS-180, respectively). For biodegradable PPCPs except NPX, their removals were high in WGS-7. Abel (2014) mentioned that SAT with several days ( 5 days) removed pharmaceutically active compounds ( $\mathrm{PhACs}$ ) effectively. Ternes et al. (2007) reported that IBP and BZF were readily removed at above $90 \%$ in SAT with an HRT of 1 day. During the long-term operation, effective removals of carboxylic PPCPs occurred in the WGS column with an HRT of 7 days, and extending HRT had little influence on improvement of their removals. However, in short-term operation, several hours were not sufficient for the removals of carboxylic PPCPs, and their removals efficiencies increased with extending HRT. For example, removal efficiencies of KTP were $47.1 \%$, $62.0 \%, 80.4 \%$, and $99.6 \%$ in WGS-4H, WGS-8H, WGS-1, and WGS-7, respectively. In WGS-8H, the removal efficiencies of most carboxylic PPCPs (DCF, KTP, NPX, MFA, BZF, GFB, and FSM) achieved the moderate level $(>50 \%)$, and the $p \mathrm{~K}_{\mathrm{a}}$ values of these PPCPs ranged from 3.8 (FSM) to 4.5 (GFB) as well as that their $K_{\mathrm{oc}}$ values ranged from 204 (BZF) to 880 (MFA). CFB showed poorer removal than these carboxylic PPCPs. Yuan et al. (2005) mentioned that the value of $p \mathrm{~K}_{\mathrm{a}}$ reflects the proton releasing ability of a compound, and the biodegradability of phenols was positively correlated with $p \mathrm{~K}_{\mathrm{a}}$. Relatively poor removal of CFB (36.3\%) in WGS-8H could be attributed to that CFB is harder to penetrate cells and arrive at the enzyme active with lower $p \mathrm{~K}_{\mathrm{a}}$ (3.18), and HRT in SAT enhanced the removals of CFB more clearly than the removals of other carboxylic PPCPs. In addition, the removal of TEP was improved with extending HRT (from $67.3 \%$ to $82.4 \%$ in WGS), and the removal efficiencies of BP ranged from $61.5 \%$ to $94.7 \%$ with extending HRT. Zhang et al. (2011) demonstrated that biodegradations of estrogen in soil columns were enhanced by extending HRT. Drewes et al. (2006) mentioned that a longer HRT in SAT eliminated organic pollutants more effectively. For the biological communities in SAT columns with a long HRT, Idelovitch and Michail (1984) mentioned that adaptable biodegradation of organic substances required a long period of time for the development and acclimatization of the microbial population, and the growth of the adaptable biological communities was expected in SAT by extending HRT (Gielen et al., 2011; Lin et al., 2010). These indicated that the biodegradation of moderately removable PPCPs can be improved by sufficient HRT (longer than 7 days). 
347 For amide PPCPs such as ATP, IPP, CRT, and PRM, their removals were poor in WGS-7 348 column $(20.0 \%, 42.2 \%, 31.9 \%$, and $9.3 \%$, respectively), and the clear improvements on their 349 removals were not observed by extending HRT $(28.7 \%, 40.4 \%, 49.2 \%$, and $14.6 \%$ in WGS350 180, respectively). These indicated that extending HRT cannot improve the removals of amide PPCPs in SAT. All SAT columns showed negative removal on CBM. Matamoros et al. (2008a observed that CBM was persistent in subsurface flow. Gibson et al. (2010) also illustrated that CBM was resistant to degradation in soil. Furthermore, Yonetani et al. (2016) mentioned that CBM was formed by deconjugation of its metabolites (i.e., hydroxylated CBM). Maeng et al. (2011) found that the concentration of CBM increased in sand column with feeding non-chlorinated tap water. In addition, the increases of CBM were reported in wastewater treatments (Clara et al., 2005; Kreuzinger et al., 2004; Vieno et al., 2007). Thus, the negative removal on CBM in SAT could be attributed to degradation of its metabolites.

Long HRT improved the removals of PPCPs in SAT, which was in agreement with other works (Drewes et al., 2001; Grünheid et al., 2005; Matamoros et al., 2008b), but the extention of HRT requires unrealistically large space for treatment. In Figure S2 (supplementary information)Error! Reference source not found, the removal efficiencies of different categories were summarized by calculating the total concentration of each category in the influent and effluent from each column. Antibiotics were removed effectively in WGS columns even with a short HRT. The removals of analgesics, antilipdemics and others were improved by extending HRT, but the removal efficiencies of all selected categories reached above $60 \%$ in the WGS column with an HRT of 7 days. These indicated that HRT of 7 days could be sufficient for the effective removals of most PPCPs.

In summary, short HRT was sufficient for the sorption of most antibiotics except SMETH, and the effective removal of SMETH required long SAT in SAT. The removals of amide PPCPs (ATP, IPP, PRM, and CBM) were poor regardless HRT, and the removals of moderately removable PPCPs (ACEAM, TEP, and BP) were improved by extending HRT. Overall, several hours were not suitable for the effective removals of carboxylic PPCPs, and an HRT of 7 days can be sufficient for their removals.

\section{4.\# The effect of saturated conditions on PPCPs removals in SAT}

In actual SAT operation, the aerobic and anaerobic conditions were considered as key operating conditions for biodegradation (Kim et al., 2004). The effects of saturated and vadose conditions on PPCP removals were evaluated by using SAT columns packed with weathered granite soil under saturated and vadose conditions with HRT of 30 days (WGS-Sat and WGS-30) (Figure 7).

For LVFX, CAM, LCM, AZM, TRC and TRM, their removals were high (above 80\%) in WGS columns under both vadose and saturated conditions. According to the results, for the removals of antibiotics by sorption and ionic interaction, they did not vary under vadose or saturated conditions.

For highly biodegradable PPCPs (DCF, KTP, NPX, MFA, BZF, CFB, GFB, and FSM), their removals were effective regardless saturated and vadose conditions. Conkle et al. (2012) mentioned that the half-lives of GFB and IBP in wetland under anaerobic condition were longer than under aerobic condition. Jim et al. (2006) reported that PPCPs such as ACEAM, DCF, IBP, GFB, NPX and KTP were effectively biodegraded under aerobic conditions. Lin and Gan (2011) also reported that NPX, TRM, DCF, IBP, and SMETH were susceptible to biodegradation under aerobic condition. These indicated that aerobic condition enhanced the 
biodegradation of most highly biodegradable PPCPs in SAT. However, in this study, SAT

398 under saturated condition showed similar removal efficiencies of profens and antilipidemics

399 as SAT under vadose condition. The concentration of dissolved oxygen (DO) in the feed

400 water was $3.36 \mathrm{mg} / \mathrm{L}$ on average (Takabe et al., 2014), so aerobic condition was maintained

401 in the top level of the saturated column. The biodegradation of highly biodegradable PPCPs

402 could be effectively removed in the top of saturated column because of relatively high DO in

403 feed water. For amide PPCPs (ATP, IPP, CRT, PRM, and CBM), their removals were

404 consistently poor (less than 50\%) under saturated and vadose conditions. These indicated that

405

406

407

408 vadose condition had little influence on the resistance of amide PPCPs in SAT.

Though most selected PPCPs were similar on their removals in WGS columns under saturated and vadose conditions, the removal efficiencies of SMETH were $46.4 \%$ and $72.7 \%$ in WGS-Sat and WGS-30, respectively. The vadose condition was helpful to make the air trapped in soil and increase the oxygen concentration in the soil to support the aerobic biodegradation of SMETH. Monteiro and Boxall (2009) mentioned that aerobic bacteria contributed to the removals of SMETH in soil. Similarly, Liu et al. (2010) and Baumgarten et al. (2011) reported that aerobic bacteria could degrade SMETH easily under vadose condition. Compared with profens and antilipdemics, the removal of SMETH arrived at the effective level in WGS-180 column, and this indicated that the biodegradation of SMETH need longterm contact time. In SAT under vadose condition, sufficient DO concentration was expected in deeper levels. Thus, continuous aerobic condition was expected in the SAT column under vadose condition to support the long-term biodegradation of SMETH.

Highly biodegradable PPCPs such as profens and antilipdemics were removed effectively regardless of vadose conditions, but the removals of SMETH and CRT were improved under vadose condition. From the perspective of practical use, saturated condition has been sufficient for the removals of PPCPs in SAT, and sufficient DO in $\mathrm{A}_{2} \mathrm{O}$ water support the biodegradation of most biodegradable PPCPs in SAT. Cooperation of SAT and CAS treatment $\left(\mathrm{A}_{2} \mathrm{O}\right.$ process) was practical for wastewater reclamation to remove micropollutants.

Comparing SAT with studied soil treatments (Table 5), WGS-7 showed effective removals on antibiotics as well as other treatments. For BZF, CFB, and FSM (halogenated carboxylic acids), SAT achieved higher removal efficiencies than other treatments. However, the negative removal of CBM was observed as well as the work of Drewes et al. (2002). These indicated that additional advanced treatment was necessary to improve the control of micropollutants during wastewater reclamation.

\section{4.\# CONCLUSIONS}

Packing materials had little influence on the characteristics of biodegradation in SAT, but WGS possessing high values of TOC, CEC and specific area was suitable to remove antibiotics by sorption.

Removal efficiencies of biodegradable PPCPs (i.e., carboxylic PPCPs) were improved by extending HRT. However, for most PPCPs except SMETH, ATP, CRT and ACEAM, their removals were sufficiently high in the WGS column with an HRT of 7 days.

Wastewater effluent after $\mathrm{A}_{2} \mathrm{O}$ process provided sufficient DO for biodegradation of most selected PPCPs, but the removals of SMETH and CRT were more effective under vadose 
condition than saturated condition. Thus, cooperation of SAT and CAS treatment $\left(\mathrm{A}_{2} \mathrm{O}\right.$ process) was practical for wastewater reclamation to control micropollutants.

\section{ACKNOWLEDGEMENTS} for measuring DOC and maintaining SAT pilot-scale reactors, and Kyoto City Waterworks Bureau for providing the feed water and technical supports for this project.

\section{REFERENCES}

Abel C. Soil Aquifer Treatment: Assessment and Applicability of Primary Effluent Reuse in Developing Countries. UNESCO-IHE, Institute for Water Education, 2014.

Accinelli C, Koskinen WC, Becker JM, Sadowsky MJ. Environmental fate of two sulfonamide antimicrobial agents in soil. Journal of Agricultural and Food Chemistry 2007; 55: 2677-2682.

Aga DS. Fate of pharmaceuticals in the environment and in water treatment systems: CRC Press, 2007.

Allaire S, Del Castillo J, Juneau V. Sorption kinetics of chlortetracyline and tylosin on sandy loam and heavy clay soils. Journal of Environmental Quality 2006; 35: 969-972.

Bailey GW, White JL. Factors influencing the adsorption, desorption, and movement of pesticides in soil. Single Pesticide Volume: The Triazine Herbicides. Springer, 1970, pp. 29-92.

Baumgarten B, Jaehrig J, Reemtsma T, Jekel M. Long term laboratory column experiments to simulate bank filtration: Factors controlling removal of sulfamethoxazole. Water Research 2011; 45: 211-220.

Berglund B, Khan GA, Weisner SE, Ehde PM, Fick J, Lindgren P-E. Efficient removal of antibiotics in surfaceflow constructed wetlands, with no observed impact on antibiotic resistance genes. Science of the Total Environment 2014; 476: 29-37.

Bot A, Benites J. The importance of soil organic matter: key to drought-resistant soil and sustained food production: Food \& Agriculture Org., 2005.

Boxall AB, Blackwell P, Cavallo R, Kay P, Tolls J. The sorption and transport of a sulphonamide antibiotic in soil systems. Toxicology Letters 2002; 131: 19-28.

Boyd GR, Reemtsma H, Grimm DA, Mitra S. Pharmaceuticals and personal care products (PPCPs) in surface and treated waters of Louisiana, USA and Ontario, Canada. Science of the total Environment 2003; 311: 135-149.

Chen J, Liu Y-S, Su H-C, Ying G-G, Liu F, Liu S-S, et al. Removal of antibiotics and antibiotic resistance genes in rural wastewater by an integrated constructed wetland. Environmental Science and Pollution Research 2015; 22: 1794-1803.

Clara M, Strenn B, Gans O, Martinez E, Kreuzinger N, Kroiss H. Removal of selected pharmaceuticals, fragrances and endocrine disrupting compounds in a membrane bioreactor and conventional wastewater treatment plants. Water research 2005; 39: 4797-4807.

Colucci MS, Bork H, Topp E. Persistence of estrogenic hormones in agricultural soils. Journal of Environmental Quality 2001; 30: 2070-2076.

Conkle JL, Gan J, Anderson MA. Degradation and sorption of commonly detected PPCPs in wetland sediments under aerobic and anaerobic conditions. Journal of Soils and Sediments 2012; 12: 1164-1173.

Drewes J, Heberer T, Reddersen K. Fate of pharmaceuticals during indirect potable reuse. 2 nd World Water Congress: Environmental Monitoring, Contaminants and Pathogens. 46, 2002, pp. 73-80.

Drewes JE, Fox P, Jekel M. Occurrence of iodinated X-ray contrast media in domestic effluents and their fate during indirect potable reuse. Journal of Environmental Science and Health, Part A 2001; 36: 1633 1645.

Drewes JE, Quanrud DM, Amy GL, Westerhoff PK. Character of organic matter in soil-aquifer treatment systems. Journal of Environmental Engineering 2006; 132: 1447-1458.

Drillia P, Stamatelatou K, Lyberatos G. Fate and mobility of pharmaceuticals in solid matrices. Chemosphere 2005; 60: 1034-1044.

Ellis JB. Pharmaceutical and personal care products (PPCPs) in urban receiving waters. Environmental Pollution 2006; 144: 184-189.

Fang Y, Karnjanapiboonwong A, Chase DA, Wang J, Morse AN, Anderson TA. Occurrence, fate, and persistence of gemfibrozil in water and soil. Environmental Toxicology and Chemistry 2012; 31: 550555.

Figueroa RA, Leonard A, MacKay AA. Modeling tetracycline antibiotic sorption to clays. Environmental Science and Technology 2004; 38: 476-483. 
Focazio MJ, Kolpin DW, Barnes KK, Furlong ET, Meyer MT, Zaugg SD, et al. A national reconnaissance for pharmaceuticals and other organic wastewater contaminants in the United States-II) Untreated drinking water sources. Science of the Total Environment 2008; 402: 201-216.

Göbel A, Thomsen A, McArdell CS, Joss A, Giger W. Occurrence and sorption behavior of sulfonamides, macrolides, and trimethoprim in activated sludge treatment. Environmental Science and Technology 2005; 39: 3981-3989.

Gao J, Pedersen JA. Adsorption of sulfonamide antimicrobial agents to clay minerals. Environmental Science and Technology 2005; 39: 9509-9516.

Gerba CP, Powelson DK, Yahya MT, Wilson LG, Amy GL. Fate of viruses in treated sewage effluent during soil aquifer treatment designed for wastewater reclamation and reuse. Water Science \& Technology 1991; 24: 95-102.

Gibson R, Durán-Álvarez JC, Estrada KL, Chávez A, Jiménez Cisneros B. Accumulation and leaching potential of some pharmaceuticals and potential endocrine disruptors in soils irrigated with wastewater in the Tula Valley, Mexico. Chemosphere 2010; 81: 1437-1445.

Gielen GJ, Clinton PW, Van den Heuvel MR, Kimberley MO, Greenfield LG. Influence of sewage and pharmaceuticals on soil microbial function. Environmental Toxicology and Chemistry 2011; 30: 10861095.

Gimbel R, Graham NJD, Collins MR. Recent progress in slow sand and alternative biofiltration processes: IWA Publishing, 2006.

Golet EM, Xifra I, Siegrist H, Alder AC, Giger W. Environmental exposure assessment of fluoroquinolone antibacterial agents from sewage to soil. Environmental Science and Technology 2003; 37: 3243-3249.

Grünheid S, Amy G, Jekel M. Removal of bulk dissolved organic carbon (DOC) and trace organic compounds by bank filtration and artificial recharge. Water research 2005; 39: 3219-3228.

Hernández M, Magarzo C, Lemaire B. Degradation of emerging contaminants in reclaimed water through soil aquifer treatment (SAT). Journal of Water Reuse and Desalination 2012; 2: 157-164.

Hoppe-Jones C, Dickenson ER, Drewes JE. The role of microbial adaptation and biodegradable dissolved organic carbon on the attenuation of trace organic chemicals during groundwater recharge. Science of the Total Environment 2012; 437: 137-144.

Hua J, An P, Winter J, Gallert C. Elimination of COD, microorganisms and pharmaceuticals from sewage by trickling through sandy soil below leaking sewers. Water Research 2003; 37: 4395-4404.

Idelovitch E, Michail M. Soil-aquifer treatment: a new approach to an old method of wastewater reuse. Journal (Water Pollution Control Federation) 1984: 936-943.

Jim TY, Bouwer EJ, Coelhan M. Occurrence and biodegradability studies of selected pharmaceuticals and personal care products in sewage effluent. Agricultural Water Management 2006; 86: 72-80.

Karnjanapiboonwong A, Suski JG, Shah AA, Cai Q, Morse AN, Anderson TA. Occurrence of PPCPs at a wastewater treatment plant and in soil and groundwater at a land application site. Water, Air, and Soil Pollution 2011; 216: 257-273.

Kasprzyk-Hordern B, Dinsdale RM, Guwy AJ. Illicit drugs and pharmaceuticals in the environment-Forensic applications of environmental data, Part 2: Pharmaceuticals as chemical markers of faecal water contamination. Environmental Pollution 2009; 157: 1778-1786.

Khan Z, Anjaneyulu Y. Analysis of the distribution coefficients and mobility characteristics of phenols in different soil types. Environmental Geology 2005; 48: 1-5.

Kim J-W, Jang H-S, Kim J-G, Ishibashi H, Hirano M, Nasu K, et al. Occurrence of pharmaceutical and personal care products (PPCPs) in surface water from Mankyung River, South Korea. Journal of Health Science 2009; 55: 249-258.

Kim J-W, Kim J, Choi H, Schwartz FW. Modeling the fate and transport of organic and nitrogen species in soil aquifer treatment process. Water Science and Technology 2004; 50: 255-261.

Kim J, Yoon S, Lee S, Narumiya M, Nakada N, Han I, et al. Occurrence and fate of PPCPs wastewater treatment plants in Korea. 2nd International Conference on Environment and Industrial Innovation, Singapore. 35, 2012, pp. 57-61.

Kimura K, Hara H, Watanabe Y. Elimination of selected acidic pharmaceuticals from municipal wastewater by an activated sludge system and membrane bioreactors. Environmental Science and Technology 2007; 41: 3708-3714.

Kobayashi Y, Okuda T, Yamashita N, tanaka H, Tanaka S, Fujii S, et al. The Occurrence of Pharmaceuticals during Advanced Wastewater Treatment. Environmental Engineering Research 2006; 43: 65-72.

Kraigher B, Kosjek T, Heath E, Kompare B, Mandic-Mulec I. Influence of pharmaceutical residues on the structure of activated sludge bacterial communities in wastewater treatment bioreactors. Water Research 2008; 42: 4578-4588. 
Kreuzinger N, Clara M, Strenn B, Kroiss H. Relevance of the sludge retention time (SRT) as design criteria for wastewater treatment plants for the removal of endocrine disruptors and pharmaceuticals from wastewater. Water Science and Technology 2004; 50: 149-156.

Lin AY-C, Lin C-A, Tung H-H, Chary NS. Potential for biodegradation and sorption of acetaminophen, caffeine, propranolol and acebutolol in lab-scale aqueous environments. Journal of Hazardous Materials 2010; 183: 242-250.

Lin AY-C, Yu T-H, Lateef SK. Removal of pharmaceuticals in secondary wastewater treatment processes in Taiwan. Journal of Hazardous Materials 2009; 167: 1163-1169.

Lin K, Gan J. Sorption and degradation of wastewater-associated non-steroidal anti-inflammatory drugs and antibiotics in soils. Chemosphere 2011; 83: 240-246.

Liu F, Ying G-G, Yang J-F, Zhou L-J, Tao R, Wang L, et al. Dissipation of sulfamethoxazole, trimethoprim and tylosin in a soil under aerobic and anoxic conditions. Environmental Chemistry 2010; 7: 370-376.

Maeng SK, Sharma SK, Abel CD, Magic-Knezev A, Amy GL. Role of biodegradation in the removal of pharmaceutically active compounds with different bulk organic matter characteristics through managed aquifer recharge: batch and column studies. Water Research 2011; 45: 4722-4736.

Massmann G, Greskowiak J, Dünnbier U, Zuehlke S, Knappe A, Pekdeger A. The impact of variable temperatures on the redox conditions and the behaviour of pharmaceutical residues during artificial recharge. Journal of Hydrology 2006; 328: 141-156.

Matamoros V, Arias C, Brix H, Bayona JM. Preliminary screening of small-scale domestic wastewater treatment systems for removal of pharmaceutical and personal care products. Water Research 2009; 43: $55-62$.

Matamoros V, Caselles-Osorio A, García J, Bayona JM. Behaviour of pharmaceutical products and biodegradation intermediates in horizontal subsurface flow constructed wetland. A microcosm experiment. Science of the total environment 2008a; 394: 171-176.

Matamoros V, García J, Bayona JM. Organic micropollutant removal in a full-scale surface flow constructed wetland fed with secondary effluent. Water Research 2008b; 42: 653-660.

Monteiro SC, Boxall A. Factors affecting the degradation of pharmaceuticals in agricultural soils. Environmental Toxicology and Chemistry 2009; 28: 2546-2554.

Nakada N, Shinohara H, Murata A, Kiri K, Managaki S, Sato N, et al. Removal of selected pharmaceuticals and personal care products (PPCPs) and endocrine-disrupting chemicals (EDCs) during sand filtration and ozonation at a municipal sewage treatment plant. Water Research 2007; 41: 4373-4382.

Nakada N, Tanishima T, Shinohara H, Kiri K, Takada H. Pharmaceutical chemicals and endocrine disrupters in municipal wastewater in Tokyo and their removal during activated sludge treatment. Water Research 2006; 40: 3297-3303.

Nakada N, Yasojima M, Okayasu Y, Komori K, Suzuki Y. Mass balance analysis of triclosan, diethyltoluamide, crotamiton and carbamazepine in sewage treatment plants. Water Science and Technology 2010; 61: 1739-1747.

Narumiya M, Okuda T, Nakada N, Yamashita N, Tanaka H, Sato K, et al. Occurrence and Fate of Pharmaceuticals and Personal Care Products during Wastewater Treatments. Environmental Engineering Research 2009; 46.

Okuda T, Kobayashi Y, Nagao R, Yamashita N, Tanaka H, Tanaka S, et al. Removal efficiency of 66 pharmaceuticals during wastewater treatment process in Japan. Water Science and Technology 2008; 57: 65-71.

Okuda T, Yamashita N, Tanaka H, Matsukawa H, Tanabe K. Development of extraction method of pharmaceuticals and their occurrences found in Japanese wastewater treatment plants. Environment International 2009; 35: 815-820.

Onesios KM, Jim TY, Bouwer EJ. Biodegradation and removal of pharmaceuticals and personal care products in treatment systems: a review. Biodegradation 2009; 20: 441-466.

Ort C, Lawrence MG, Rieckermann Jr, Joss A. Sampling for pharmaceuticals and personal care products (PPCPs) and illicit drugs in wastewater systems: are your conclusions valid? A critical review. Environmental science \& technology 2010; 44: 6024-6035.

Picó Y, Andreu V. Fluoroquinolones in soil--risks and challenges. Analytical and Bioanalytical Chemistry 2007; 387: $1287-1299$.

Polar JA. The fate of pharmaceuticals after wastewater treatment. Florida water resources journal 2007; 6: 26.

Radjenović J, Petrović M, Barceló D. Fate and distribution of pharmaceuticals in wastewater and sewage sludge of the conventional activated sludge (CAS) and advanced membrane bioreactor (MBR) treatment. Water Research 2009; 43: 831-841.

Reif R, Besancon A, Le Corre K, Jefferson B, Lema J, Omil F. Comparison of PPCPs removal on a paralleloperated MBR and AS system and evaluation of effluent post-treatment on vertical flow reed beds. Water Science and Technology 2011; 63: 2411. 
Reungoat J, Escher B, Macova M, Keller J. Biofiltration of wastewater treatment plant effluent: Effective removal of pharmaceuticals and personal care products and reduction of toxicity. Water Research 2011; 45: 2751-2762.

Sassman SA, Lee LS. Sorption of three tetracyclines by several soils: assessing the role of $\mathrm{pH}$ and cation exchange. Environmental Science and Technology 2005; 39: 7452-7459.

Schaffer M, Kröger KF, Nödler K, Ayora C, Carrera J, Hernández M, et al. Influence of a compost layer on the attenuation of 28 selected organic micropollutants under realistic soil aquifer treatment conditions: Insights from a large scale column experiment. Water Research 2015; 74: 110-121.

Schlüsener MP, Bester K. Persistence of antibiotics such as macrolides, tiamulin and salinomycin in soil. Environmental Pollution 2006; 143: 565-571.

Shinohara H, Murakami M, Managaki S, Kojima S, Takada H, Sato N, et al. Removal of water-soluble organic micro-pollutants by soil infiltration. Environmental Science 2006; 19: 435-444.

Sibley SD, Pedersen JA. Interaction of the macrolide antimicrobial clarithromycin with dissolved humic acid. Environmental Science and Technology 2007; 42: 422-428.

Song W, Guo M. Residual veterinary pharmaceuticals in animal manures and their environmental behaviors in soils. Applied Manure and Nutrient Chemistry for Sustainable Agriculture and Environment. Springer, 2014, pp. 23-52.

Stoob K, Singer HP, Stettler S, Hartmann N, Mueller SR, Stamm CH. Exhaustive extraction of sulfonamide antibiotics from aged agricultural soils using pressurized liquid extraction. Journal of Chromatography A 2006; 1128: 1-9.

Stuer-Lauridsen F, Birkved M, Hansen L, Lützhøft H-CH, Halling-Sørensen B. Environmental risk assessment of human pharmaceuticals in Denmark after normal therapeutic use. Chemosphere 2000; 40: 783-793.

Suárez S, Carballa M, Omil F, Lema JM. How are pharmaceutical and personal care products (PPCPs) removed from urban wastewaters? Reviews in Environmental Science and Bio/Technology 2008; 7: 125-138.

Takabe Y, Kameda I, Suzuki R, Nishimura F, Itoh S. Changes of microbial substrate metabolic patterns through a wastewater reuse process, including WWTP and SAT concerning depth. Water Research 2014; 60: $105-117$.

Teerlink J, Martínez-Hernández V, Higgins CP, Drewes JE. Removal of trace organic chemicals in onsite wastewater soil treatment units: A laboratory experiment. Water research 2012; 46: 5174-5184.

Ternes TA, Bonerz M, Herrmann N, Teiser B, Andersen HR. Irrigation of treated wastewater in Braunschweig, Germany: an option to remove pharmaceuticals and musk fragrances. Chemosphere 2007; 66: 894-904.

Tiehm A, Schmidt N, Stieber M, Sacher F, Wolf L, Hoetzl H. Biodegradation of pharmaceutical compounds and their occurrence in the Jordan Valley. Water Resources Management 2011; 25: 1195-1203.

Tixier C, Singer HP, Oellers S, Müller SR. Occurrence and fate of carbamazepine, clofibric acid, diclofenac, ibuprofen, ketoprofen, and naproxen in surface waters. Environmental Science and Technology 2003; 37: 1061-1068.

Tolls J. Sorption of veterinary pharmaceuticals in soils: a review. Environmental Science and Technology 2001; 35: 3397-3406.

Tootchi L. By-Product Formation from Select Pharmaceuticals during Drinking Water Ozonation Treatment. Department of Civil and Environmental Engineering. Master. University of Windsor, 2010.

Uslu MÖ, Yediler A, Balcıoglu IA, Schulte-Hostede S. Analysis and sorption behavior of fluoroquinolones in solid matrices. Water, Air, and Soil Pollution 2008; 190: 55-63.

van Wijhe M. The history of caffeine as used in anaesthesia. In: Diz J, Franco A, Bacon D, Rupreht J, Alvarez J, editors. HISTORY OF ANESTHESIA. 1242, 2002, pp. 101-103.

Vieno N, Tuhkanen T, Kronberg L. Elimination of pharmaceuticals in sewage treatment plants in Finland. Water research 2007; 41: 1001-1012.

Waltman EL, Venables BJ, Waller WT. Triclosan in a North Texas wastewater treatment plant and the influent and effluent of an experimental constructed wetland. Environmental toxicology and chemistry 2006; 25: 367-372.

Wu C, Spongberg AL, Witter JD, Fang M, Czajkowski KP, Ames A. Dissipation and leaching potential of selected pharmaceutically active compounds in soils amended with biosolids. Archives of environmental contamination and toxicology 2010; 59: 343-351.

$\mathrm{Xu} \mathrm{J,} \mathrm{Wu} \mathrm{L,} \mathrm{Chang} \mathrm{AC.} \mathrm{Degradation} \mathrm{and} \mathrm{adsorption} \mathrm{of} \mathrm{selected} \mathrm{pharmaceuticals} \mathrm{and} \mathrm{personal} \mathrm{care} \mathrm{products}$ (PPCPs) in agricultural soils. Chemosphere 2009; 77: 1299-1305.

Yang J-F, Ying G-G, Yang L-H, Zhao J-L, Liu F, Tao R, et al. Degradation behavior of sulfadiazine in soils under different conditions. Journal of Environmental Science and Health Part B 2009; 44: 241-248.

Yang X, Flowers RC, Weinberg HS, Singer PC. Occurrence and removal of pharmaceuticals and personal care products (PPCPs) in an advanced wastewater reclamation plant. Water Research 2011; 45: 5218-5228. 
Yasojima M, Nakada N, Komori K, Suzuki Y, Tanaka H. Occurrence of levofloxacin, clarithromycin and azithromycin in wastewater treatment plant in Japan. Water Science and Technology 2006; 53: $227-$ 233.

Yonetani T, Echigo S, Itoh S. Fate of Selected Pharmaceuticals and Their Metabolites in Soil Aquifer Treatment. Jorunal of Water Reuse and Desalination 2016 (In press).

Yonetani T, Phattarapattamawong S, Echigo S, Morita Y, Ohkouchi Y, Itoh S. Fate of Pharmaceutical and Personal Care Products in Treated Sewage during Soil Aquifer Treatment. Journal of Japan Society of Civil Engineers, Ser. G (Environmental Research) 2012; 68: III_419-III_428.

Yoon MK, Drewes JE, Amy GL. Fate of bulk and trace organics during a simulated aquifer recharge and recovery (ARR)-ozone hybrid process. Chemosphere 2013; 93: 2055-2062.

Yu L, Fink G, Wintgens T, Melin T, Ternes TA. Sorption behavior of potential organic wastewater indicators with soils. Water Research 2009; 43: 951-960.

Yuan X, Lu G, Su L. Correlation study of toxicity of substituted phenols to river bacteria and their biodegradability in river water. Biomedical and Environmental Sciences 2005; 18: 281.

Zhang X, Zhao X, Zhang M, Wu Q-y. Safety evaluation of an artificial groundwater recharge system for reclaimed water reuse based on bioassays. Desalination 2011; 281: 185-189. 
698

699

700

701

702

703

704

705

706

707

708

709

710

\section{LIST OF TABLES}

Table 1 List of the target PPCPs.

Table 2 Soil characteristics of WGS, sand and Toyoura standard sand.

Table 3 Water quality of $\mathrm{A}_{2} \mathrm{O}$ water.

Table 4 Operating conditions of the columns.

Table 5 Comparison of removal efficiencies of target PPCPs between this study and previous studies. 
Table 1 List of the target PPCPs.

\begin{tabular}{|c|c|c|c|c|c|}
\hline Compounds & $\boldsymbol{K}_{\mathrm{oc}}$ & $\mathrm{p} K \mathrm{a}$ & $\mathrm{COOH}$ & Use/category & Abbr. \\
\hline Ampicillin & 6.423 & $2.5,7.3$ & + & Antibiotic & AMP \\
\hline Azithromycin & 3100 & 8.74 & - & Antibiotic & AZM \\
\hline Chlortetracycline & 6.575 & 1.4 & & Antibiotic & CTC \\
\hline Ciprofloxacin & 61000 & 6.09 & + & Antibiotic & CPFX \\
\hline Clarithromycin & 150 & 8.99 & - & Antibiotic & CAM \\
\hline Enrofloxacin & 15800 & $5,8-9$ & + & Antibiotic & NRFX \\
\hline Erythromycin & 570 & 8.88 & & Antibiotic & ERY \\
\hline Levofloxacin & 44143 & $6.24,8.74$ & + & Antibiotic & LVFX \\
\hline Lincomycin & 69 & 7.6 & - & Antibiotic & LCM \\
\hline Norfloxacin & & $6.34,8.75$ & + & Antibiotic & NRFX \\
\hline Oxytetracycline & 4.319 & 9.5 & - & Antibiotic & OTC \\
\hline Sulfadimethoxine & 285.2 & 6.91 & & Antibiotic & SDIME \\
\hline Sulfamethazine & 208 & 7.59 & & Antibiotic & SMT \\
\hline Sulfamethoxazole & 72 & $1.6,5.7$ & & Antibiotic & SMETH \\
\hline Tetracycline & 0.69 & 3.3 & - & Antibiotic & $\mathrm{TC}$ \\
\hline Triclosan & 19952 & 7.9 & & Antibiotic & TRC \\
\hline Trimethoprim & 75 & 7.12 & - & Antibiotic & TRM \\
\hline Acetaminophen & 41 & 9.6 & + & Analgesic & ACEAM \\
\hline Antipyrine & 11.65 & 4.15 & & Analgesic & ATP \\
\hline Aspirin & 100 & & + & Analgesic & ASP \\
\hline Crotamiton & 244 & 10.45 & & Analgesic & CRT \\
\hline Diclofenac & 245 & 4.5 & + & Analgesic & $\mathrm{DCF}$ \\
\hline Fenoprofen & 233.8 & 4.15 & + & Analgesic & FNP \\
\hline Ibuprofen & 3400 & 9.38 & + & Analgesic & IBP \\
\hline Isopropylantipyrine & 84.96 & 4.91 & & Analgesic & IPP \\
\hline Ketoprofen & 229 & 4.20 & + & Analgesic & KTP \\
\hline Mefenamic acid & 880.1 & 4.20 & + & Analgesic & MFA \\
\hline Naproxen & 330 & 4.45 & + & Analgesic & NPX \\
\hline Atenolol & 4.081 & 3.83 & & Antiarrhythmic & ATL \\
\hline Disopyramide & 288 & 3.18 & & Antiarrhythmic & DSP \\
\hline Bezafibrate & 204 & 3.61 & + & Antilipidemic & $\mathrm{BZF}$ \\
\hline Clofibric acid & 43.7 & 3.18 & + & Antilipidemic & CFB \\
\hline Gemfibrozil & 430 & 4.5 & + & Antilipidemic & GFB \\
\hline DEET & 300 & & & Rejectant & DEET \\
\hline Benzophenone & 517 & & & Ultraviolet absorber & $\mathrm{BP}$ \\
\hline Caffeine & 741 & & & Cardiac & $\mathrm{CAF}$ \\
\hline Carbamazepine & 510 & 13.9 & & Antipilepsy & $\mathrm{CBM}$ \\
\hline Primidone & 23.84 & 11.5 & & Antipilepsy & PRM \\
\hline Sulpiride & 13.85 & 9.12 & & Peptic ulcer & SLP \\
\hline Theophylline & 517 & & & Cardiac & TEP \\
\hline Diltiazem & 197.8 & 8.06 & & Blood-vessel dilator & DTZ \\
\hline Furosemide & 302 & $3.8,7.5$ & + & Blood-vessel dilator & FSM \\
\hline
\end{tabular}

Table 2 Soil characteristics of WGS, sand and Toyoura standard sand. 


\begin{tabular}{cccc}
\hline & & & \\
Ignition loss (\%) & 2.74 & 1.36 & 0.376 \\
Water content (\%) & 1.1 & 0.567 & 0.0654 \\
$\mathrm{pH}$ & 6.53 & 6.64 & 6.87 \\
CEC (meq/100mg) & 15.6 & 2.39 & 0.192 \\
TOC (\%) & 0.0159 & 0.0094 & 0.0144 \\
Porosity & 0.40 & 0.44 & 0.43 \\
Particle size distribution (0.05 mm-, \%) & $>99$ & $>99$ & 100 \\
Specific surface $\left(\mathrm{m}^{2} / \mathrm{g}\right)$ & 5.95 & 2.40 & 0.812 \\
\hline
\end{tabular}

714

715

\begin{tabular}{llcl}
\multicolumn{4}{c}{ Table 3 Water quality of $\mathrm{A}_{2} \mathrm{O}$ water. } \\
\hline $\mathbf{p H}$ & $\mathbf{D O}(\mathbf{m g} / \mathbf{L})$ & $\mathbf{D O C}(\mathbf{m g} / \mathbf{L})$ & $\mathbf{U V}_{254}\left(\mathbf{c m}^{-\mathbf{1}}\right)$ \\
& & & \\
\hline $6.43(6.37-6.50)$ & $1.47(1.13-1.75)$ & $3.68(3.31-4.19)$ & $0.082(0.070-0.128)$
\end{tabular}

\begin{tabular}{llll}
\hline DTP-P (mg/L) & DTN-N(mg/L) & $\mathbf{N H}_{4}{ }^{+}-\mathbf{N}(\mathbf{m g} / \mathbf{L})$ & $\mathbf{N O}_{2}{ }^{-}-\mathbf{N}(\mathbf{m g} / \mathbf{L})$ \\
\hline $0.400(0.280-0.805)$ & $4.43(3.87-4.89)$ & $<0.02(<0.02-0.56)$ & $0.046(0.014-0.080)$
\end{tabular}

\begin{tabular}{ll}
\hline $\mathrm{NO}_{3}{ }^{-}-\mathrm{N}(\mathrm{mg} / \mathrm{L})$ & Organic-N(mg/L) \\
\hline $3.41(3.26-3.46)$ & $0.92(0.53-0.97)$
\end{tabular}

716

717

718 
Table 4 Operating conditions of the columns.

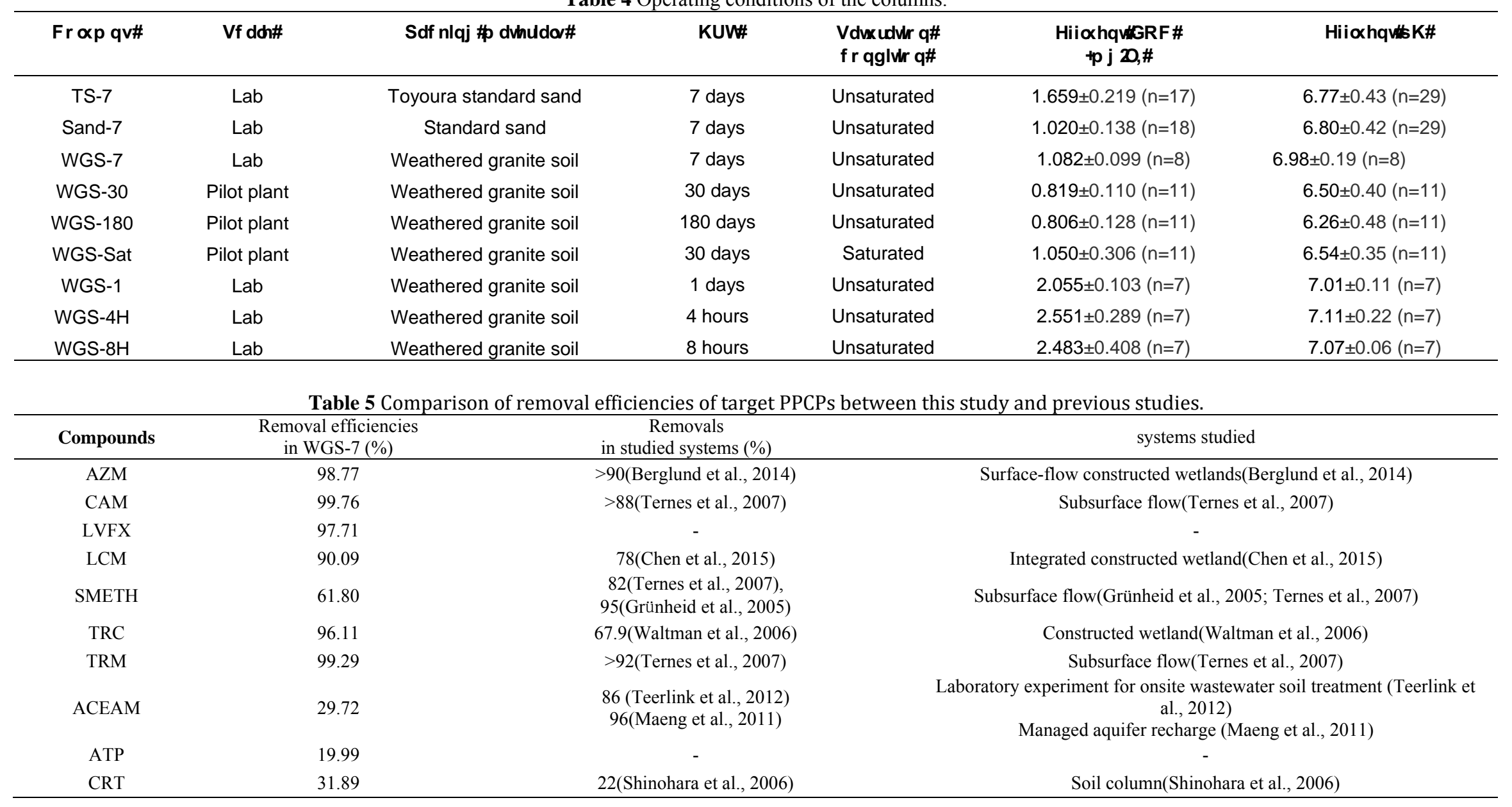


67.26

98.9
96(Massmann et al., 2006), (>87, $>98$ )(Drewes et al., 2002) 71.0(Hua et al., 2003)

97(Matamoros et al., 2008b)

45-46(Shinohara et al., 2006)

92(Matamoros et al., 2008b)

$>99$ (Drewes et al., 2002)

$>93$ (Ternes et al., 2007)

$>80$ (Ternes et al., 2007)

36, 32 (Matamoros et al., 2008b),

48.3(Hua et al., 2003),

$>79$ (Ternes et al., 2007)

$>99$ (Drewes et al., 2002)

48(Teerlink et al., 2012)

$>60$ (Yoon et al., 2013)

$>88$ (Ternes et al., 2007)

5(Matamoros et al., 2008a)

$<-5$ (Drewes et al., 2002)

94.41

$\sim 96$ (Wu et al., 2010)
Constructed wetland(Massmann et al., 2006), Subsurface flow(Drewes et al., 2002) lab column(Hua et al., 2003)

Constructed wetland(Matamoros et al., 2008b)

Soil column(Shinohara et al., 2006)

Constructed wetland(Matamoros et al., 2008b)

Subsurface flow(Drewes et al., 2002)

Subsurface flow(Ternes et al., 2007)

Subsurface flow(Ternes et al., 2007)

Constructed wetland(Matamoros et al., 2008b),

Lab columns(Hua et al., 2003),

Subsurface flow(Ternes et al., 2007)

Subsurface flow(Drewes et al., 2002)

Laboratory experiment for onsite wastewater soil treatment (Teerlink et al., 2012)

Aquifer recharge and recovery (Yoon et al., 2013)

Subsurface flow(Ternes et al., 2007)

Subsurface flow(Matamoros et al., 2008a)

Subsurface flow(Drewes et al., 2002)

Soil amended with biosolids(Wu et al., 2010)

Constructed wetland(Matamoros et al., 2009) 


\section{LIST OF FIGURES}

Figure 1 Schematic of the SAT reactor under vadose condition.

Figure 2 The distribution of $\mathrm{PPCP}$ categories in the $\mathrm{A}_{2} \mathrm{O}$ water.

Figure 3 PPCP concentrations in the $\mathrm{A}_{2} \mathrm{O}$ water $(\mathrm{n}=11)$.

Figure 4 Removal efficiencies of PPCPs in SAT columns with different packing materials.

Figure 5 Removal efficiencies of PPCPs in WGS columns with different HRTs (long-term scale).

Figure 6 Removal efficiencies of PPCPs in WGS columns with different HRTs (short-term scale).

Figure 7 Removal efficiencies of PPCPs in WGS columns under saturated and unsaturated conditions (HRT of 30 days). 


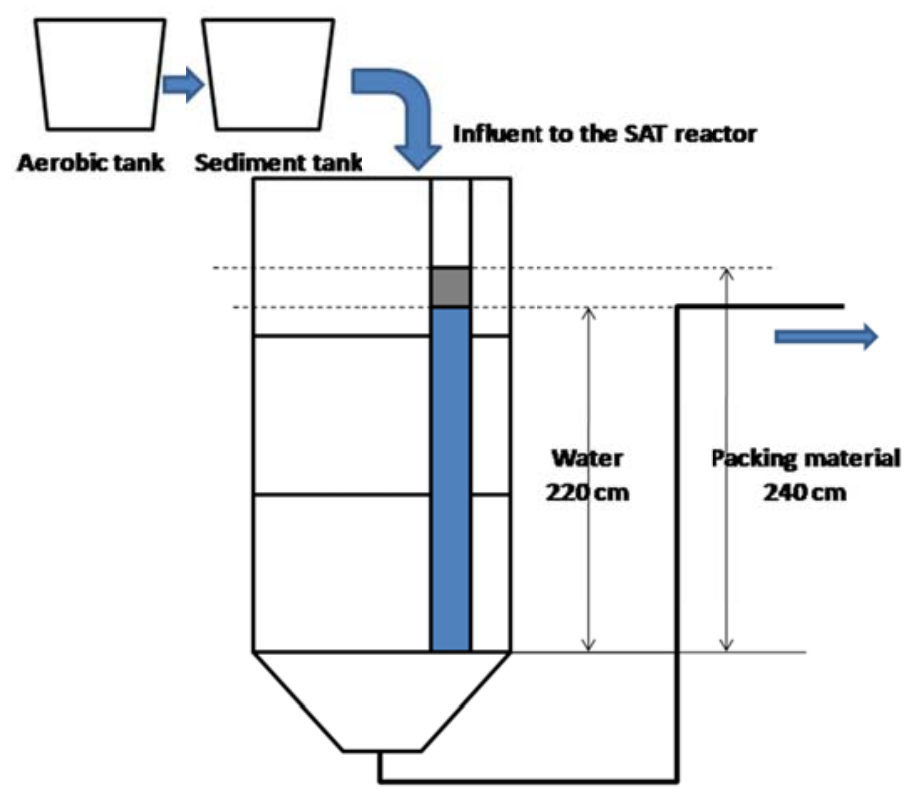

Figure 1 Schematic of the SAT reactor under vadose condition.

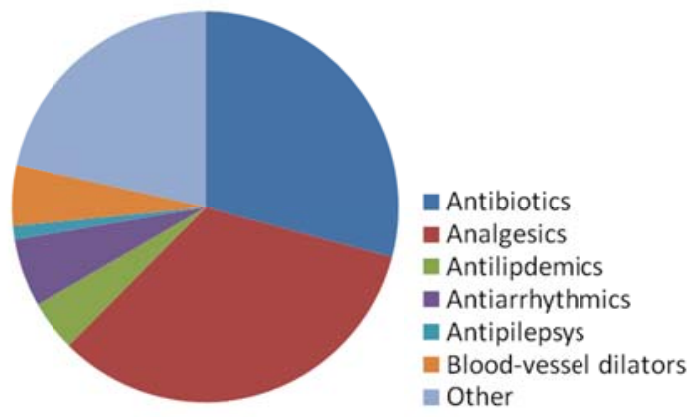

Figure 2 The distribution of PPCP categories in the $\mathrm{A}_{2} \mathrm{O}$ water. 


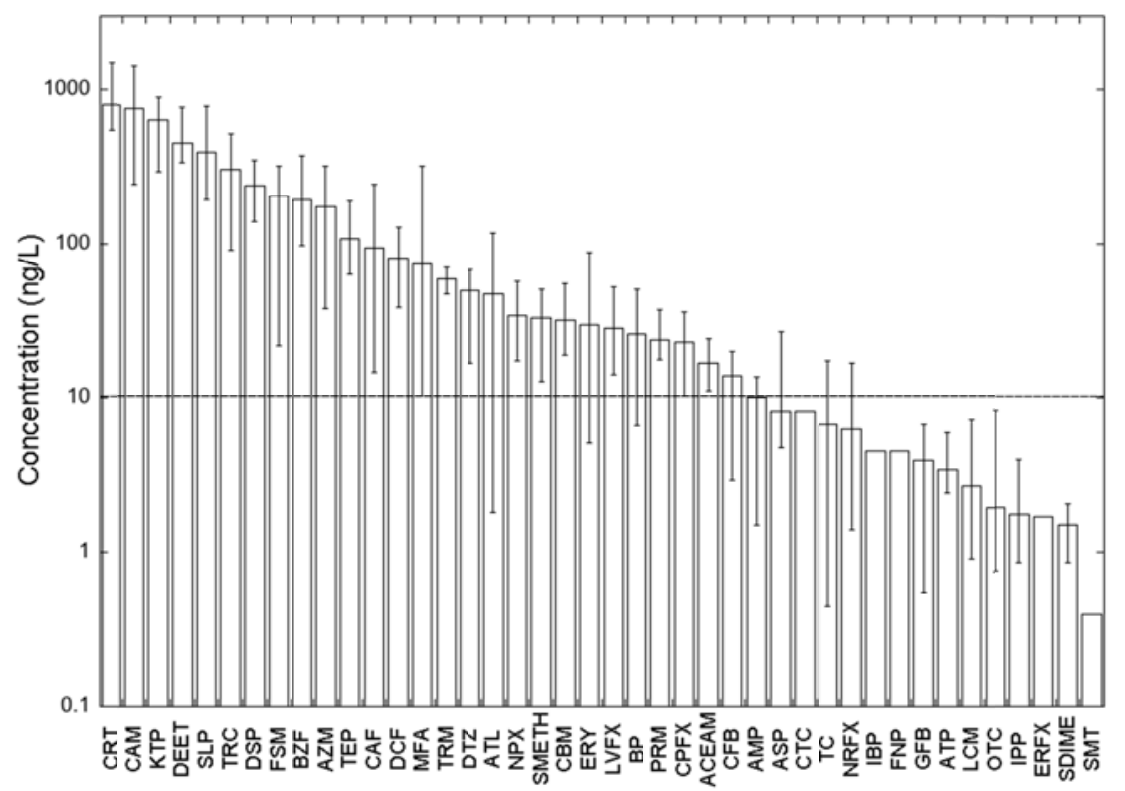

Figure 3 PPCP concentrations in the $\mathrm{A}_{2} \mathrm{O}$ water $(\mathrm{n}=11)$.

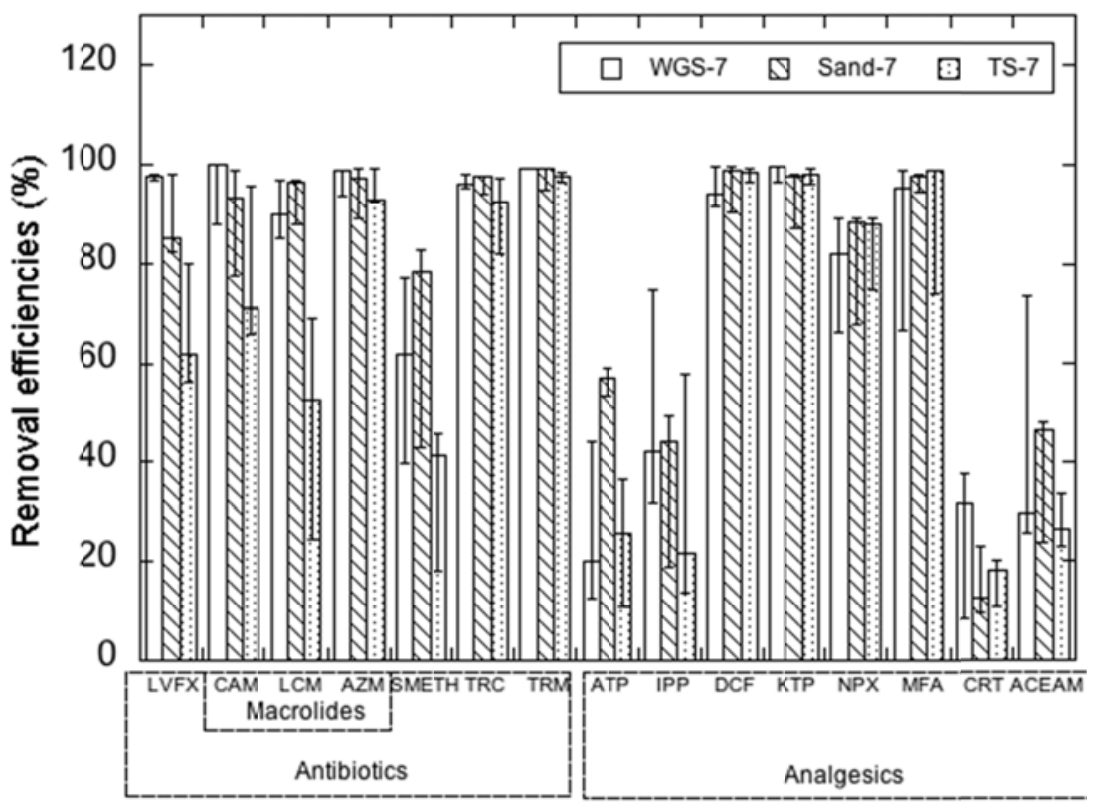




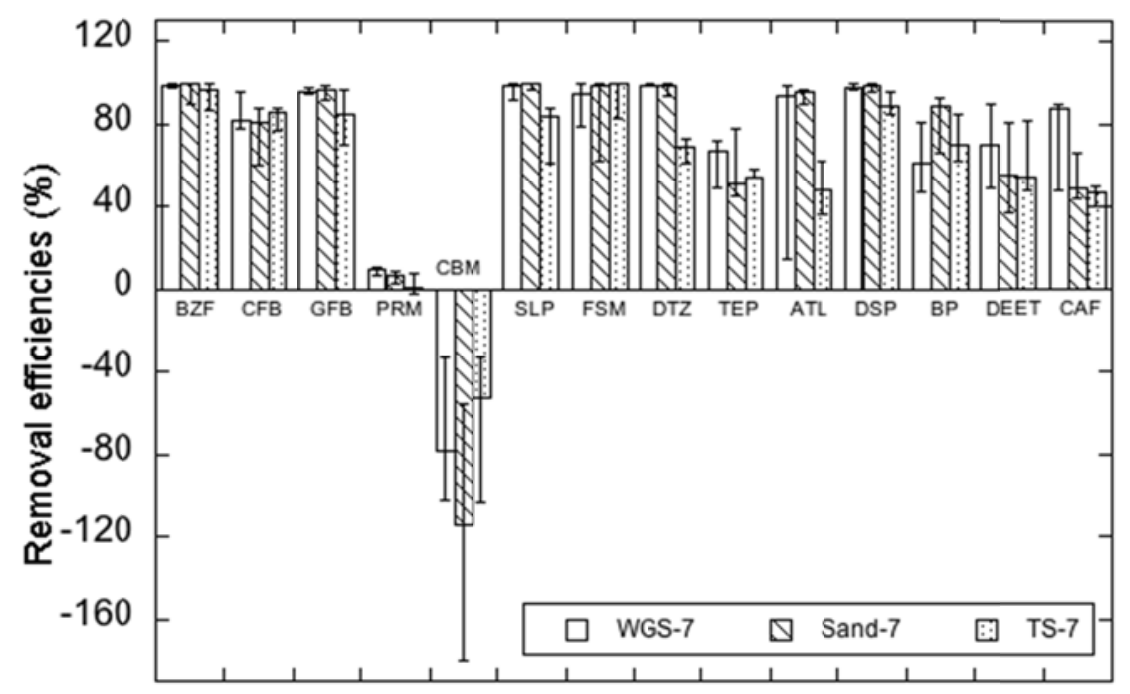

Figure 4 Removal efficiencies of PPCPs in SAT columns with different packing materials.

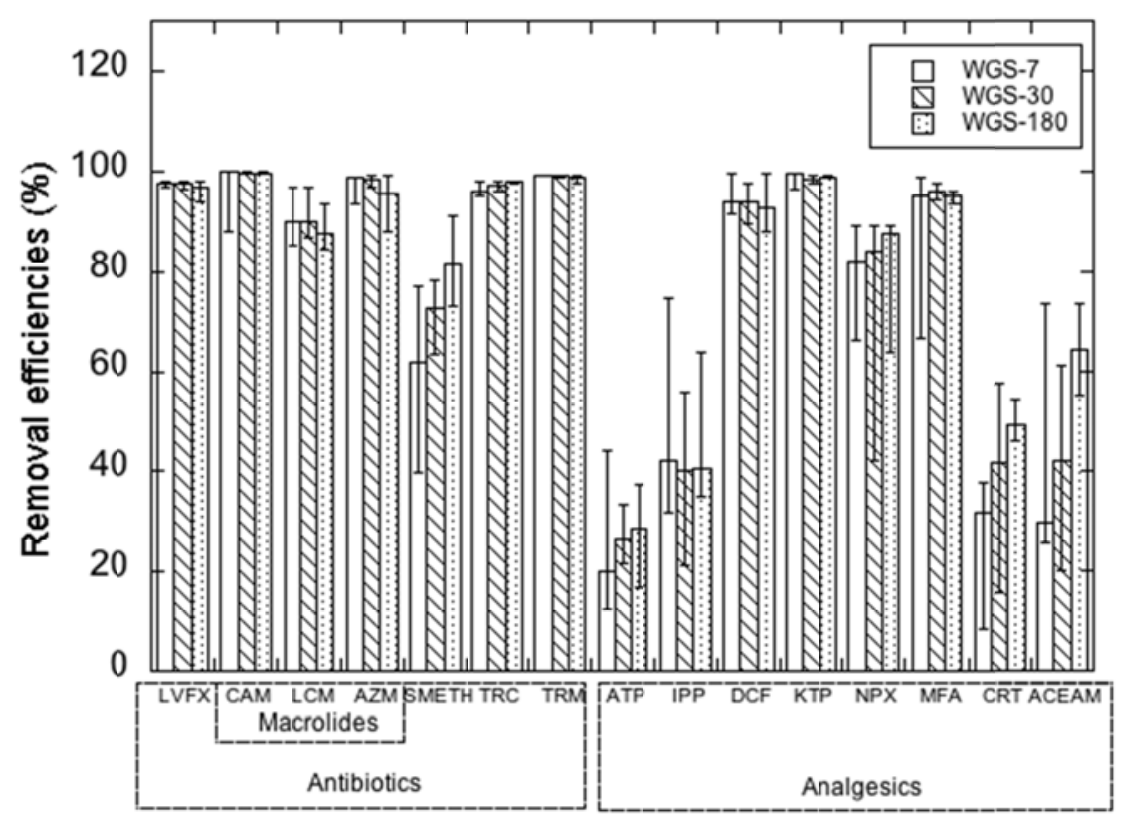




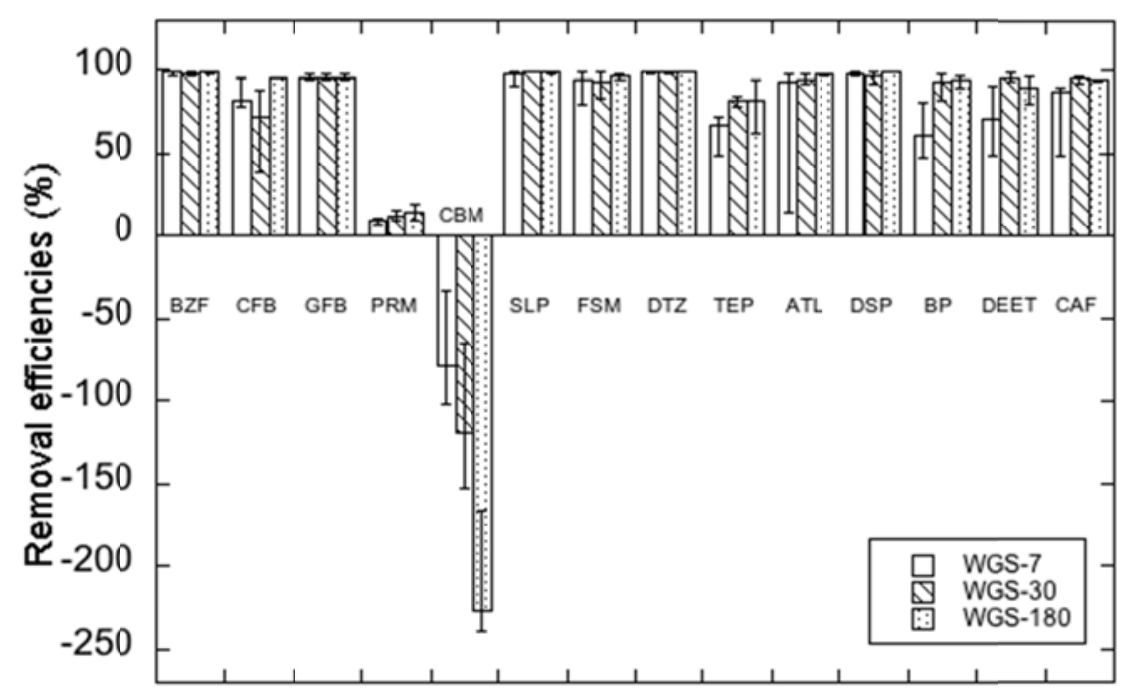

Figure 5 Removal efficiencies of PPCPs in WGS columns with different HRTs (long-term scale).

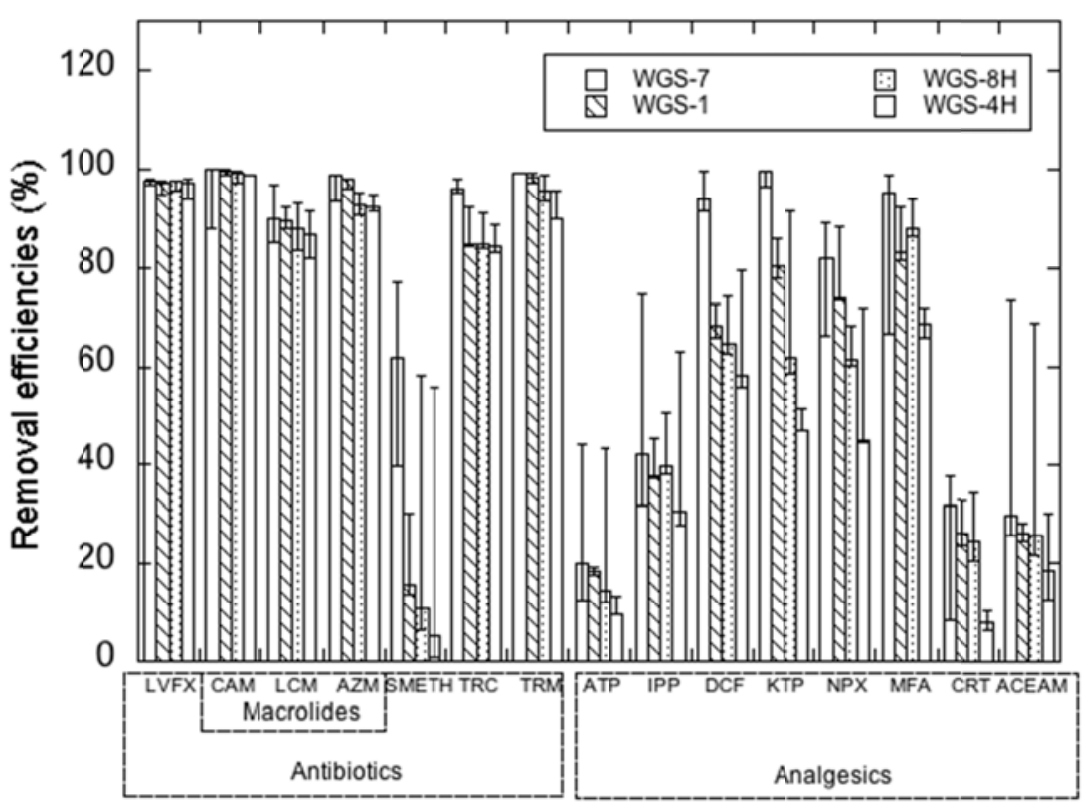




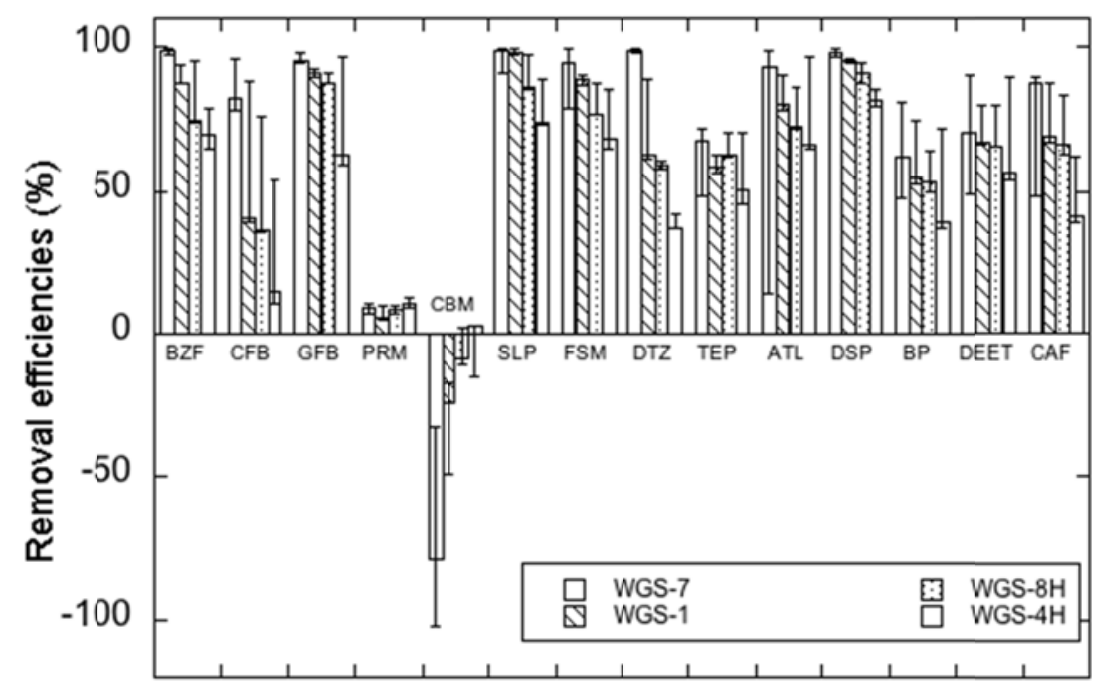

Figure 6 Removal efficiencies of PPCPs in WGS columns with different HRTs (short-term scale).

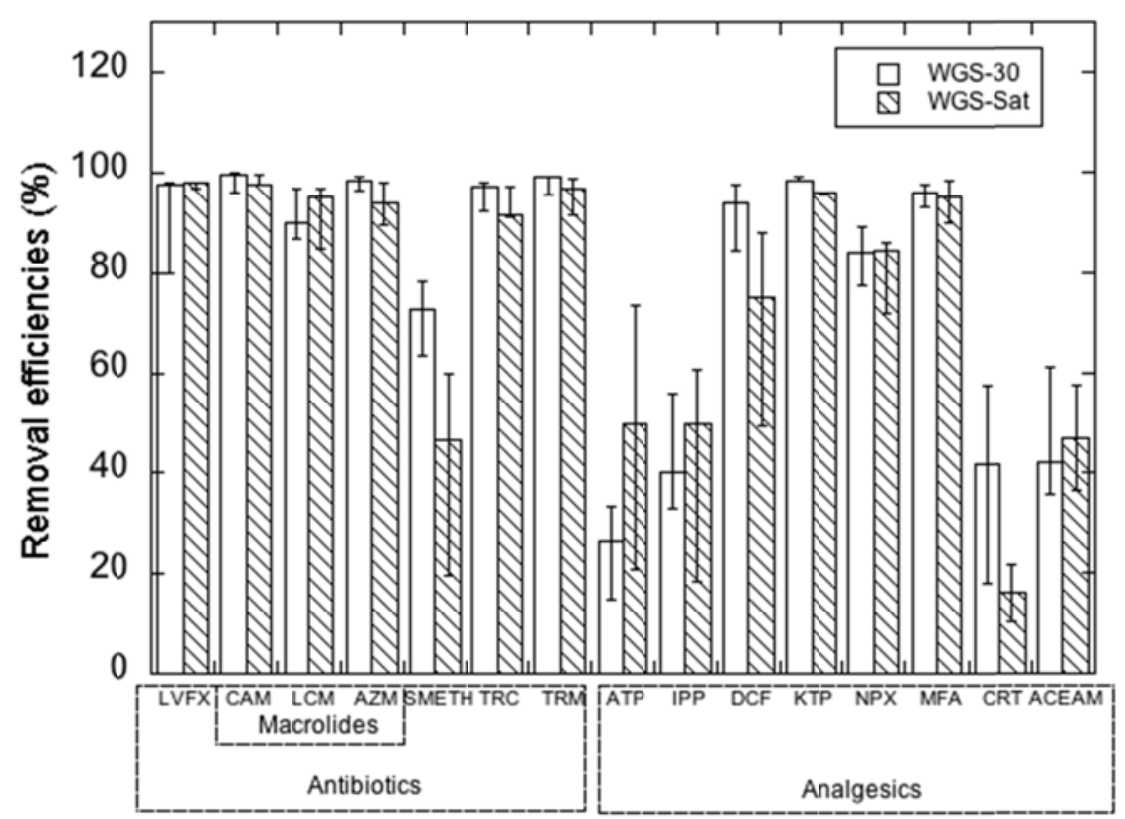




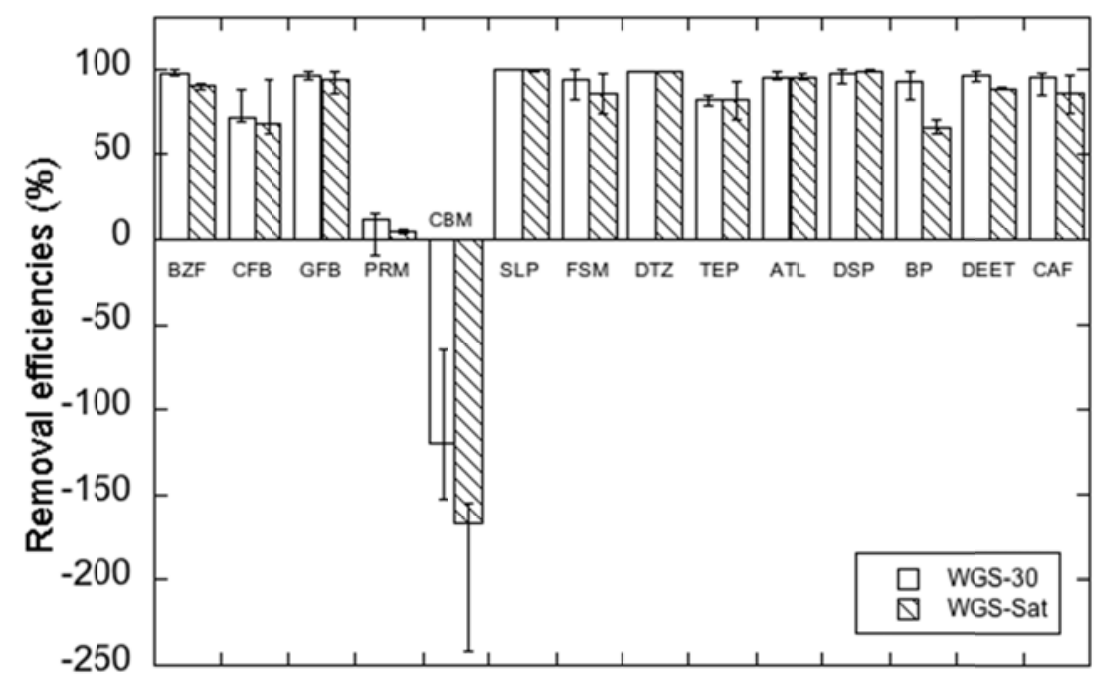

Figure 7 Removal efficiencies of PPCPs in WGS columns under saturated and unsaturated conditions (HRT of 30 days). 